\title{
WOOD QUALITY OF THE SPECIES Cedrelinga cateniformis Ducke THROUGH ULTRASONIC INSPECTION
}

\author{
Luis Shuseki Yoza ${ }^{1 *}$, Jose Sánchez Blanco², Jorge Luis Monteiro de Matos ${ }^{3}$, Márcio Pereira da Rocha ${ }^{3}$, Ivan \\ Venson $^{3}$ \\ ${ }^{1 *}$ Universidad Nacional Agraria La Molina, Departamento de Física y Meteorologia, Lima, Perú, lyoza@lamolina.edu.pe \\ ${ }^{2}$ Universidad Nacional Agraria La Molina, Laboratorio de Acústica, Lima, Perú, josecarlos_sb@yahoo.com \\ ${ }^{3}$ Universidade Federal do Paraná, Departamento de Engenharia e Tecnologia Florestal, Curitiba, Paraná, Brazil. jmatos.ufpr@gmail.com \\ ${ }^{3}$ Universidade Federal do Paraná, Departamento de Engenharia e Tecnologia Florestal, Curitiba, Paraná, Brazil. mprocha01@ gmail.com \\ ${ }^{3}$ Universidade Federal do Paraná, Departamento de Engenharia e Tecnologia Florestal, Curitiba, Paraná, Brazil. venson.ivan @ gmail.com
}

Received for publication on: 05/11/2018 - Accepted for publication on: 29/03/2020

\begin{abstract}
Resumo
Qualidade da madeira da espécie Cedrelinga cateniformis Ducke através da inspeção ultrasônica. Desenvolver um método de inspeção em blocos de elementos estruturais de madeira utilizando técnicas não destrutivas é a proposta do presente estudo preliminar, para o qual se tomaram três blocos de madeira Cedrelinga cateniformis Ducke perfurados longitudinalmente em forma de grade, efetuando-se em seguida medições transversais de velocidades de ultrassom com as quais foram elaborados gráficos em 2D. Posteriormente os blocos foram cortados, gerando corpos de prova transversais dos quais foram determinadas as densidades aparentes. Os gráficos de ambos parâmetros foram comparados, permitindo visualizar zonas de qualidade dos blocos em faixas de velocidades e densidades o que permite propor preliminarmente um protocolo de inspeção com testes de ultrassom de elementos estruturais.

Palavras chave: velocidades transversais de ultrassom, quadriculado, gráfico 2D, técnicas não destrutivas.
\end{abstract}

\begin{abstract}
The present work proposes a method of inspecting structural elements of wood blocks using non-destructive techniques. For this, three blocks of Cedrelinga cateniformis Ducke wood were longitudinally perforated in a grid form, then transversal ultrasound velocities were measured and used to make 2D graphics. Afterwards, the blocks were cut to make transversal specimens that were used to determine apparent densities. The graphs of both parameters were compared to visualize quality zones in the blocks from velocity and density bands. From this, a preliminary inspection protocol using ultrasound tests of structural elements was proposed.

Keywords: Transversal velocities of ultrasound, quadrate, 2D graphic, non-destructive techniques.
\end{abstract}

\section{INTRODUCTION}

The main objective of this study was to develop an inspection method to evaluate the quality of structural wooden blocks and identify the different zones (good to low quality) caused by factors such as internal structure variation or deterioration by external agents, using non-destructive ultrasound tests (NDT) located punctually. For this, ultrasound wave propagation velocities were measured in the transverse direction of the wooden blocks and local apparent densities of the material were determined by locating the study points in a longitudinal-transversal square grid and then correlating the results using $2 \mathrm{D}$ graphs.

The results of this study serve as a basis for in situ studies of the structural elements of historical monuments in Peru since the NDT technique is the most appropriate due to its low interference. Using ultrasound waves of FAKOPP equipment on pine beams extracted from the Moreira Méjico Cathedral, Carrillo, Sotomayor, Raya (2019) indicated that the transverse velocities measured in cross-sections are more sensitive to structural and quality changes, noting that longitudinal velocities are more homogeneous in these beams.

Using transverse ultrasound waves on samples of Pinus sylvestris and Pinus nigra, Rodríguez et al. (2011) reported that a degree of wood rot and resistance can be established, establishing the need for a reference value of transverse velocity, e.g., 1,400 m. $\mathrm{s}^{-1}$, indicating that values lower than this were deterioration zones. Emerson $e t$ al. (2002) also used ultrasound tests to characterize Douglas fir (Pseudotsuga menziesii) blocks (14 x 8 x 120 inches) taken from a bridge. They used 2- and 4-inch grid squares which indicated that a block with light attack and density losses greater than $10 \%$ can reduce mechanical properties up to $80 \%$. Additionally, using samples of deteriorating beams, they obtained graphs with 300, 150 and 90 measurement points, respectively, for the propagation time of ultrasound waves, characterizing the zones as attacked by rot, when viewing the damaged zones that were later contrasted with compression tests perpendicular to the fibers.

Dackermann et al. (2014) highlighted the importance of establishing the limit reference velocity for healthy wood and that the percentage of velocity loss is directly associated with the deteriorated area and indicates,

FLORESTA, Curitiba, PR, v. 50, n. 3, p. 1494 - 1499, jul/set 2020.

Yoza, L. S. et.al.

ISSN eletrônico 1982-4688 
for transversal propagation, the importance of considering the direction of the wave velocity in relation to the radial direction. Acuña et al. (2006) found a good relationship between non-destructive tests and mechanical tests to classify wood, stating that ultrasound analysis is more efficient than visual analysis. Ross et al. (1999), using ultrasound equipment of force, analyzed the relationship of the ultrasound propagation time of a $427 \mathrm{~cm}$ long piece of wood in the direction of the growth rings, moisture content and decay level, and clearly visualized the wood quality with a graph of ultrasound propagation times.

However, by comparing other nondestructive techniques such as the penetrometer and auger, Iñiguez et al. (2015) found low correlations with the overall density of Pinus radiata structural wood with determination coefficients $\left(\mathrm{r}^{2}\right)$ of 0.30 and 0.57 , respectively. Tippner, Hrivák and Kliober (2016) used FAKOPP 2D ultrasound equipment with $90 \mathrm{kHz}$ sensors on samples of Pinus Sylvestris, Abies alba and Picea abies, and concluded that the radial velocities in these species were not significantly correlated with densities, obtaining $\mathrm{r}^{2}$ values of 0.359 , 0.037 and 0.184 , respectively. Such result was also found by other authors, suggesting that other methods of relating the behavior of velocities and densities, such as those proposed here, should be sought out.

\section{MATERIALS \& METHODS}

\section{Materials}

Three wooden blocks from three Cedrelinga cateniformis Ducke trees in a sawmill located in the Pucallpa region of Peru were used for this study. The wooden blocks were oriented in the longitudinal direction and had dimensions of $12 \times 40 \times 60 \mathrm{~cm}$. The block edges were labelled as X, Y, and Z axes. The direction of the longitudinal face $(\mathrm{Z}=\mathrm{L})$ and the radial direction $(\mathrm{R})$ of each block were determined by measuring the Angle in relation to the $\mathrm{X}$ axis, obtaining values of $27^{\circ}, 31.5^{\circ}$ and $23^{\circ}$ for the blocks designated as A, B and C, respectively. In Figure 1, Block B is shown with the orthotropic directions of the blocks: longitudinal (L), radial (R) and tangential (T). The determination of the angle in relation to the growth rings is important, since its variation related to the length of the whole sample increases the variability of the results as indicated by Jaskowska and Walach (2016).
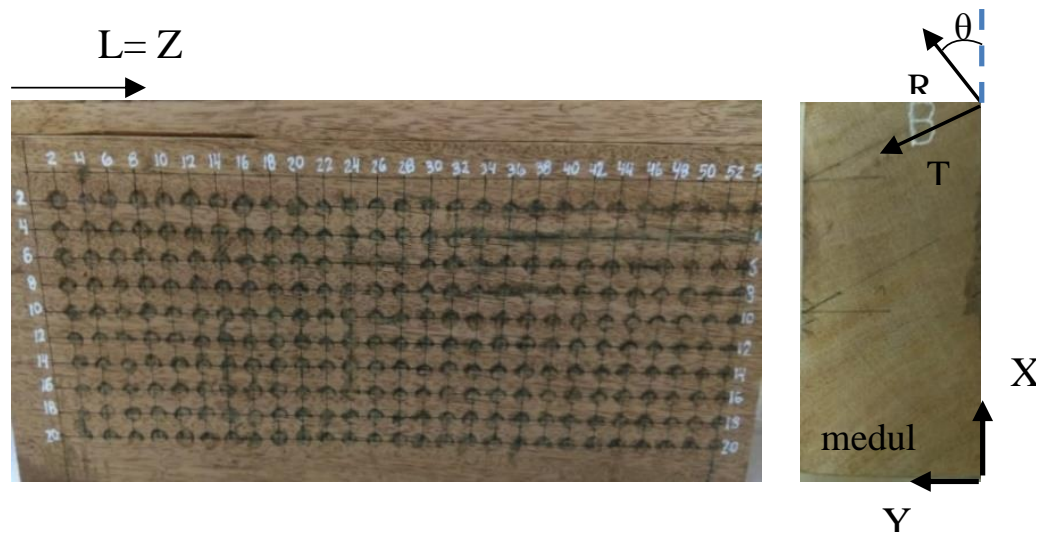

Figure 1. Block B of Cedrelinga cateniformis Ducke, ZX side with its respective squares.

Figura 1. Bloco B de Cedrelinga cateniformis Ducke, face ZX com seu respectivo quadriculado.

Blocks A, B and C were divided into 2 × $2 \mathrm{~cm}$ squares on their longitudinal-transverse side, obtaining 325, 244 and 260 squares, respectively, as shown in Figure 1. At each intercept of the squares, the transverse velocities (Y) were determined with a FAKOPP UltraSonic ultrasound equipment, with $15 \mathrm{KHz}$ longitudinal polarization sensors and resolution of $\pm 0.5 \mu$ s. Subsequently, the blocks were cut into $2 \times 2 \times 12 \mathrm{~cm}$ squares using a bench top square saw, which were then used to determine apparent densities.

\section{Methods}

Ultrasound measurements were performed at the Acoustic Contamination Laboratory at the Faculty of Sciences of the La Molina National Agrarian University, Lima-Peru. The ultrasound equipment used was the FAKOPP UltraSonic model, with $15 \mathrm{kHz}$ longitudinal polarization sensors and resolution of $\pm 0.5 \mu$ s. The equipment sensors were placed on each side of the $12 \mathrm{~cm}$-long blocks, opposite from the vertices of the drawn squares.

The velocities were measured perpendicular to the compression directions of the fibers, as proposed by Emerson et al. (2002). The data obtained was interpolated to obtain 2D velocity graphs. Subsequently, 325,244 and 260 square samples $(2 \times 2 \times 12 \mathrm{~cm}$ dimensions) were cut from Blocks A, B, and C, according to the grid shown 
in Figure 1. Afterwards, the apparent densities of the samples were determined by the immersion method and the results were used to elaborate $2 \mathrm{D}$ distribution graphs, similar to those made for velocities.

\section{RESULTS}

The Cedrelinga cateniformis Ducke blocks were stabilized and analyzed in the Acoustic Contamination and Physical-Mechanical Properties of Wood Laboratories, at the La Molina National Agrarian University. In addition, the moisture content of the three blocks was determined by the INDECOPI (NTP 251-010-2014) greenhouse method. The average humidity of the samples was $14.4 \%$, with a coefficient of variation of $1.8 \%$.

Table 1 shows the transversal velocities and densities obtained from the three blocks. Both velocity and density results do not satisfy a normal distribution, which is why a nonparametric Kruskal-Wallis test was applied in their analyzes.

Table 1. Average transversal velocities and densities of the blocks.

Tabela 1. Médias de velocidades transversais e de densidades aparentes dos blocos.

\begin{tabular}{cccc}
\hline Blocks & A & B & C \\
\hline Velocity $\left({\left.\mathrm{m} . \mathrm{s}^{-1}\right)}^{\text {CV. }(\%)}\right.$ & $1389.7(70.7)$ & $1494.3(45.0)$ & $1540.7(58.4)$ \\
\hline Density $\left(\mathrm{kg} . \mathrm{m}^{-3}\right)$ & 5,1 & 3.0 & 3.8 \\
CV. $(\%)$ & $519.1(27.5)$ & $523.9(27.1)$ & 2.3 \\
\hline
\end{tabular}

$(\mathrm{)}=$ Standard deviation, $\mathrm{CV}=$ Coefficient of variation.

\section{Transversal velocities}

Transversal ultrasound velocities (Y) of blocks A, B and C were measured based on the grid, with means presented in Table 1. Measurements made on the $\mathrm{Y}$ axis correspond to an average direction of $27.2^{\circ}$ clockwise to the tangential direction (T) (Figure1). With an average coefficient of variation of $4 \%$, the results are difficult to compare with other studies, due to the angle of spatial inclination in the radial direction of the blocks. However, this average coefficient of variation was lower than the results obtained by Yoza, Baradit and Acevedo (2015) for $2 \times 2 \times 2 \mathrm{~cm}$ and $1 \mathrm{MHz}$ samples of Cedrelinga cateniformis, which were $11.1 \%$ for the LT direction and $5.4 \%$ for the LR direction. However, such results were higher than those obtained by Baradit, Niemz and Fernandez (2013) ( $2.9 \%$ for LT and LR directions) for an average of four Chilean latifoliated species measured with a higher frequency of $2.5 \mathrm{MHz}$. The Kruscal-Wallis non-parametric statistical test with 200 samples per block indicated that the velocities obtained were not similar to each other with a contrast statistic of 336.9 and significance level of 0.000 , indicating that there is an independence regarding the velocity obtained between them.

Conversely, the velocities of each block were plotted on XZ planes, as shown in Figure 2, and a pattern of velocities in bands is noted, with the highest values found in those closest to the top of the block, e.g., zone near the bark (adult wood), and those with lower and less uniform velocities located at the bottom of the block, e.g., zone closest to the medulla (juvenile wood). In block A, there is a zone with lower velocity (in black) surrounded by a $1,300 \mathrm{~m} . \mathrm{s}^{-1}$ curve related to a rotted area, which was verified by inspecting the respective samples.

In addition, band distribution is almost non-existent in block $\mathrm{C}$, with a defective zone located in the upper left part of the block, which is presented similarly in the density graph (Figure 3). Therefore, this block was not used in the analysis, but was used for the quality criteria. Wiei et al. (2019) studied tree logs with average dimensions of $75.6 \mathrm{~cm}$ length and $23.15 \mathrm{~cm}$ diameter from the species Betula platyphylla, Fraxinus mandshurica, Ulmus pumilla y larix gmelinii in northern China and used an ARBOTOM acoustic tomography (RINNTEH) with a sensor placed on one side of the log and two others arranged symmetrically on the opposite side. These authors noticed that the velocities in the central zone decreased significantly with the presence of defects and decreased only slightly in distant longitudinal directions, corroborating the values in the cross-sectional direction found herein and reinforcing the importance of using measurements with opposing sensors.

Emerson et al (2002) studied two Douglas-fir beams using measurements of d-propagation time and ultrasound in their transverse directions, making 300 measurements for initial evaluation with 5 height measurements and 2" long grid squares, 150 measurements for average inspection with 5 height measurements and 4" long grid squares, and 90 measurements for thick inspection with 3 height measurements and 4" long grid squares. The authors observed a closed zone with high deterioration from the left edge to a distance of 15 " and another moderate quality zone up to 30 ', followed by a good quality zone to the right edge, forming longitudinal lines. The authors concluded that the third mode of evaluation did not clearly characterize the deteriorated and low-resolution zones from the good quality zones. This last procedure had a lower quality behavior than those observed for blocks A and B, especially those observed in zones of high deterioration. 

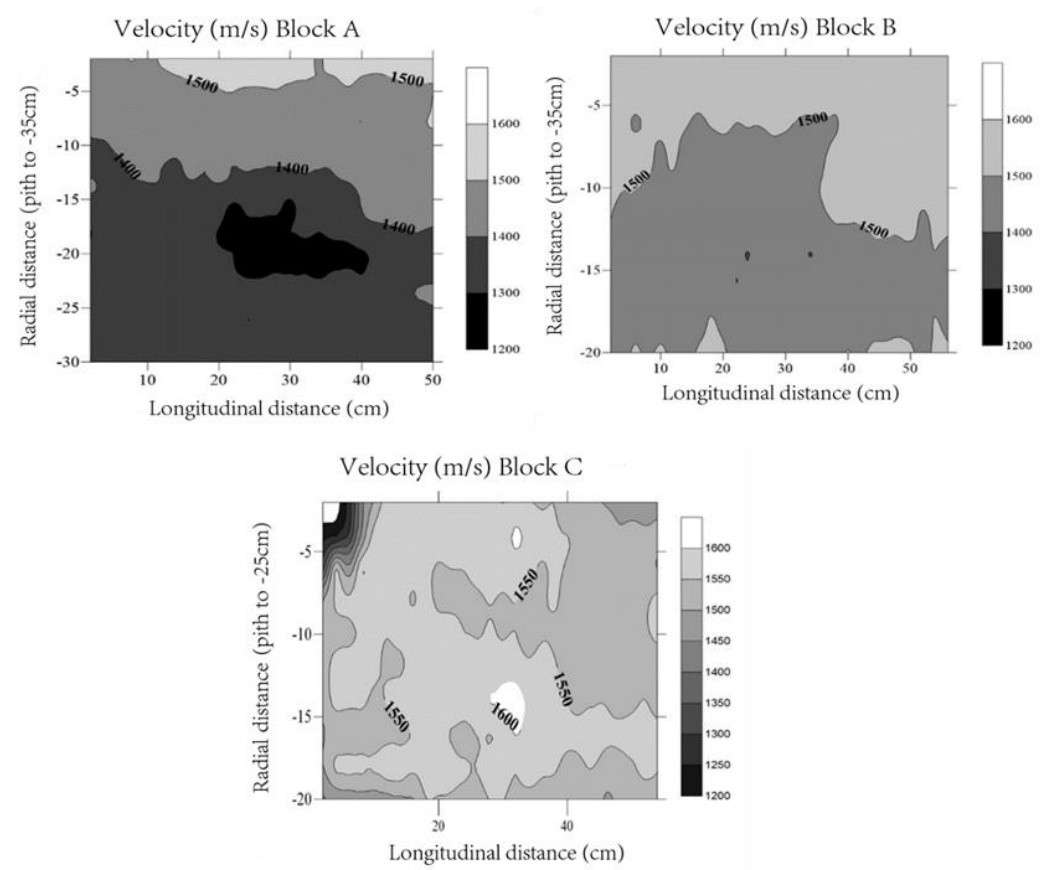

Figure 2. Graphs of transversal velocities with medulla at the bottom of the graph.

Figura 2. Gráficos de velocidades transversais localizando-se a medula na base do gráfico.

\section{Apparent Density}

The studied blocks were cut according to the established grid, obtaining samples whose densities were determined (means in Table 1). The highest average apparent density was obtained for block C, compared to blocks $\mathrm{A}$ and B, using an average moisture content of $14.4 \%$. Subsequently, the Kruskal-Wallis non-parametric test indicated that the densities of the blocks were not similar, with a contrast statistic of 173.82 and significance value of 0.000. Afterwards, the density values of each block were plotted in the XZ plane and are presented in Figure 3.

The graphs show the same characteristics as the velocities. The same apparent density band distribution is found in blocks A and B. However, in block $\mathrm{C}$, the distribution is not uniform and presents a low-density zone, confirming that this block is defective. By characterizing the species Cedrelinga cateniformis, Yoza, Baradit and Acevedo (2015) found an average density of $528.0(28.9) \mathrm{kg} \cdot \mathrm{m}^{-3}$. Herein, the value of $521.5(27.3) \mathrm{kg} \cdot \mathrm{m}^{-3}$ for blocks $\mathrm{A}$ and $\mathrm{B}$ was considered an acceptable value.
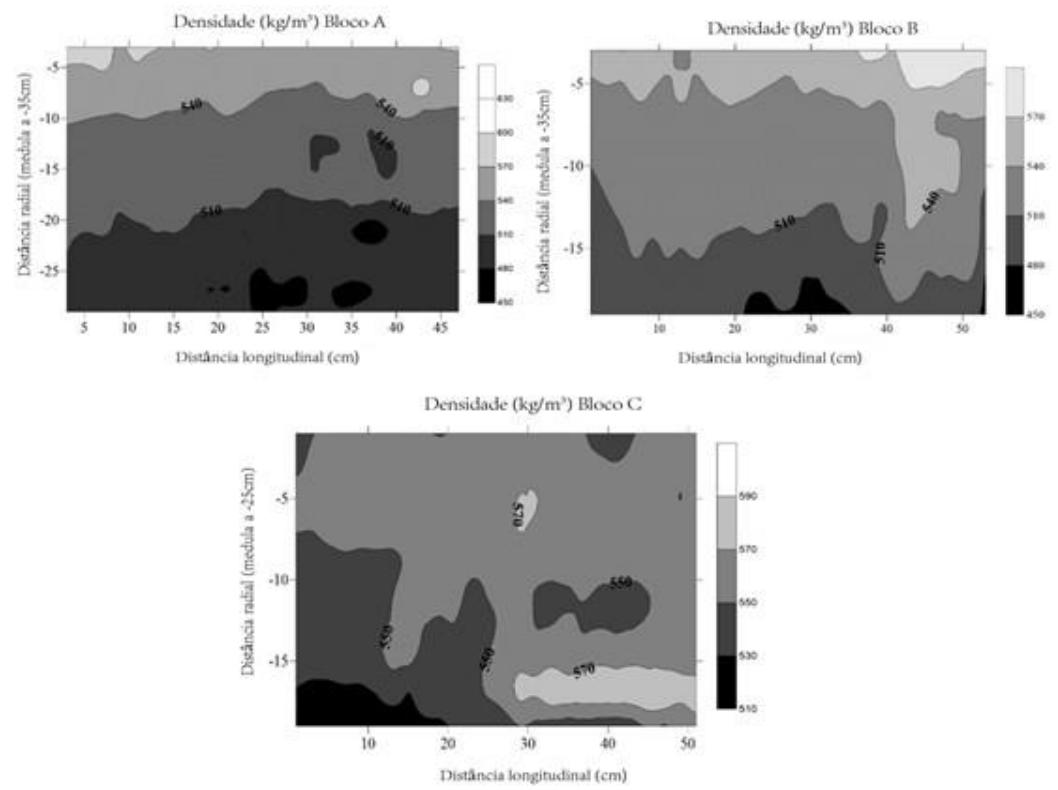

FLORESTA, Curitiba, PR, v. 50, n. 3, p. 1494 - 1499, jul/set 2020

Yoza, L. S. et.al.

ISSN eletrônico 1982-4688 
Figure 3. Graphs of densities with the medulla at the bottom of the graphs.

Figura 3. Gráficos das densidades localizando-se a medula na parte inferior dos gráficos.

\section{DISCUSSION}

\section{Transversal velocities}

Emerson (2002) presented graphs with propagation times indicating closed curves that surround the deteriorated zones up to 15 " from the left edge and good quality zones from 30" that are parallel lines in the longitudinal direction, which are very similar to those observed in blocks A and B. In block A, a dark colored zone with lower velocities $\left(<1300 \mathrm{~m} / \mathrm{s}\right.$ ) and high deterioration was observed, covering approximately $140 \mathrm{~cm}^{2}$ (Figure 2) and corresponding to a density of $\sim 510 \mathrm{~kg} . \mathrm{m}^{-3}$. However, it is important to evaluate beams with more severe deterioration to improve the resolution of the grid used.

With such information, the square grid can be used in subsequent studies if it established based on a preliminary inspection and supported by ultrasound measurements.

\section{Apparent Density}

The graphs of blocks A and B are similar, presenting uniformly distributed lines and density values comparable to those found by other authors. In addition, the samples of the rot zone of block A do not necessarily correspond to a massive attack zone in the sample, but to areas with localized attacks, which can produce changes in velocity values by increasing their wave pathways, but leave densities virtually unchanged.

\section{CONCLUSIONS}

- The evaluation method using ultrasound with transversal measurements and based on a square grid pattern allowed for a more detailed description of the quality of Cedrelinga cateniformis blocks.

- The distribution of velocities in uniform bands is associated with the same behavior of bands with good quality densities and in sharp velocity curves, indicating rot zones.

- In general, the behavior of velocities is a better indicator of the quality of structural elements, as it provides a more global assessment of the structure.

- Good quality reference velocities should be established to quantify the quality of the different zones in studies.

- In future studies, the most appropriate square grids should be defined according to visual inspection and preliminary ultrasound tests.

\section{REFERENCES}

ACUÑA, L.; DIEZ, M.R.; CASADO, M. Los ultrasonidos y la calidad de madera estructural aplicado a Pinus pinaster AIT. Boletín del CIDEU 2, v.7, n.26, 2006.

BARADIT, E.; NIEMZ, P.; FERNANDEZ-PEREZ, A. Physical And Mechanical Properties Of Some Chilean Softwoods And Hardwoods Using Ultrasound. Maderas: Ciencia y Tecnología, v.15, n.2, p.235-244, 2013.

CARRILLO, M.; SOTOMAYOR, J. RAYA, D. Structural analysis of wood beans by non-destructive methods in restoration work of the cathedral of Moreira Mexico. The International Archives of the Photogrammetry, Remote Sensing and Spatial Information Sciences, Volume XLII-2/W15, 2019

DACKERMANN, U., CREWS, K., KASAL, B., LI, J., RIGGIO, M., FRANK RINN, F., AND TANNERT, T. In situ assessment of structural timber using stress-wave measurements. Materials and Structures, 47, pp. 787-803, 2014

EMERSON, R.; POLLOCK, D.; MCLEAN, D.; FRIDLEY, K.; PELLERIN, R.; ROSS, R. Ultrasonic inspection of large bridge timbers. Forest Products Journal, v.52, n.9, 2002.

IÑIGUEZ-GONZALEZ, G.; MONTON, J.; ARRIAGA, F.; y SEGUES E. In-situ assessment of structural timber density using non-destructive and semi- destructive testing, BioResources, v.10, n.2, p 2256-2265, 2015.

INDECOPI. Norma Tecnica Peruana (NTP). Método de ensayo para la determinacion del contenido de humedad de la madera, 2014.

JASKOWSKA-LEMÁNSKA, J.; WAŁACH D. Impact of the Direction of Non-destructive Test with Respect to the Annual Growth Rings of Pine Wood, Procedia Eng.,v.161, p.925-930, 2016.

FLORESTA, Curitiba, PR, v. 50, n. 3, p. 1494 - 1499, jul/set 2020

Yoza, L. S. et.al.

ISSN eletrônico 1982-4688 
RODRIGUEZ, C; MORALES, MA J. MORALES; RUBIO DE HITA,P; PÉREZ,F. Inspeccion mediante técnicas no destructivas de un edificio histórico: oratorio de San Felipe, Informes de la Construccion, v.63, n.521, 2011.

ROSS, R.; PELLERIN, R.; VOLNY, N.; SALSIG, W.; FALK, R. Inspection of Timber Bridges Using Stress Wave Timing Nondestructive Evaluation Tools, A Guide for Use and Interpretation General Technical. Report FPL-GTR-114, Forest Products Laboratory. United States Department of Agriculture, 1999.

TIPPNER, J., HRIVNÁK, J., AND KLOIBER, M. Experimental evaluation of mechanical properties of softwood using acoustic methods, BioResourses, v.11, n.1, p.503-518, 2016

WIEI, X.; SUN, L.; SUN, Q.; XU, S.; ZHOU, H. y DU, C. Propagation velocity model of stress wave in longitudinal section of the tree in different angular direction, BioResources, v.14, n.4, p 8904-8922, 2019.

YOZA, L; BARADIT, E; ACEVEDO, M. Caracterización de las Propiedades Físico Mecánicas De Especies, Pino (Pinus Patula) Y Tornillo (Cedrelinga Cateniformis) Provenientes del Perú Utilizando Técnicas No Destructivas, Anales Científico, v.76, n.1, 2015. 